\title{
IDENTIFICATION OF PATIENT SUBGROUPS AND RISK FACTORS FOR PERSISTENT ARM/SHOULDER PAIN FOLLOWING BREAST CANCER SURGERY
}

\author{
Christine Miaskowski ${ }^{1}$, Steven M. Paul ${ }^{1}$, Bruce Cooper ${ }^{1}$, Claudia West ${ }^{1}$, Jon D. Levine ${ }^{2}$, \\ Charles Elboim ${ }^{4}$, Deborah Hamolsky ${ }^{1}$, Gary Abrams ${ }^{2}$, Judith Luce ${ }^{2}$, Anand Dhruva ${ }^{2}$, Dale \\ J. Langford ${ }^{1}$, John D. Merriman ${ }^{1}$, Kord Kober ${ }^{1}$, Christina Baggott ${ }^{1}$, Heather Leutwyler ${ }^{1}$, and \\ Bradley E. Aouizerat ${ }^{1,3}$ \\ ${ }^{1}$ School of Nursing University of California, San Francisco, CA \\ ${ }^{2}$ School of Medicine University of California, San Francisco, CA \\ ${ }^{3}$ Institute for Human Genetics, University of California, San Francisco, CA \\ ${ }^{4}$ Redwood Regional Medical Group, Santa Rosa, CA
}

\begin{abstract}
Purpose-In this prospective, longitudinal study, we extend our findings on persistent breast pain in patients $(n=398)$ following breast cancer surgery and evaluate the prevalence and characteristics of persistent pain in the arm/shoulder In addition, differences in the severity of common symptoms and quality of life outcomes measured prior to surgery, among the arm pain classes, were evaluated.
\end{abstract}

Methods and sample-Patients were recruited from Breast Care Centers located in a Comprehensive Cancer Center, two public hospitals, and four community practices. Patients were assessed prior to and monthly for six months following breast cancer surgery.

Results-Using growth mixture modeling, patients were classified into no (41.6\%), mild (23.6\%), and moderate (34.8\%) arm pain classes based on ratings of worst arm/shoulder pain. Compared to the no pain class, patients in the moderate pain class were significantly younger, had a higher body mass index, and were more likely to report preoperative breast pain and swelling in the affected breast. In addition, patients in the moderate pain class reported higher levels of depression, anxiety, and sleep disturbance than the no pain class.

(C) 2013 Elsevier Ltd. All rights reserved

Address correspondence to: Christine Miaskowski, RN, PhD, FAAN Professor Department of Physiological Nursing University of California 2 Koret Way - N631Y San Francisco, CA 94143-0610 415-476-9407 (phone) 415-476-8899 (fax) chris.miaskowski@nursing.ucsf.edu.

Publisher's Disclaimer: This is a PDF file of an unedited manuscript that has been accepted for publication. As a service to our customers we are providing this early version of the manuscript. The manuscript will undergo copyediting, typesetting, and review of the resulting proof before it is published in its final citable form. Please note that during the production process errors may be discovered which could affect the content, and all legal disclaimers that apply to the journal pertain.

Conflict of interest and disclosures: There are no conflicts of interest to disclose.

Authorship: All of the authors have made substantial contributions to this manuscript and provided final approval for submission of the paper. 
Conclusions-Findings suggest that approximately 35\% of women experience persistent levels of moderate arm/shoulder pain in the first six months following breast cancer surgery. Moderate arm/shoulder pain is associated with clinically meaningful decrements in functional status and quality of life.

\section{Keywords}

arm pain; shoulder pain; persistent postsurgical pain; risk factors; breast cancer surgery; growth mixture modeling; latent class analysis; chronic pain

\section{INTRODUCTION}

Persistent pain following breast cancer surgery occurs in $25 \%$ to $60 \%$ of patients (Gartner, et al., 2009). This pain problem is associated with mood disturbance, decrements in functional status, and decreases in quality of life (QOL) (Belfer, et al., 2013; Stevens, Dibble, \& Miaskowski, 1995). However, in their recent review of persistent pain following breast cancer treatment, Andersen and Kehlet (2011) identified numerous limitations in the research studies done to date on this significant clinical problem. In addition to inconsistencies in the measurement of pain, only a limited number of studies have assessed for persistent pain in both the breast and shoulder/arm following breast cancer surgery.

In one of the earliest studies that compared occurrence rates based on anatomic site (Tasmuth, von Smitten, \& Kalso, 1996), 10\% of patients who underwent either mastectomy or breast conserving surgery reported pain in the ipsilateral arm. At one year, 39\% of these patients reported persistent ipsilateral arm pain. Other studies have compared the prevalence of pain within the larger context of "arm and shoulder morbidities" in patients who had breast conserving surgery versus mastectomy (Carpenter, et al., 1999; Nesvold, Dahl, Lokkevik, Marit Mengshoel, \& Fossa, 2008; Vilholm, Cold, Rasmussen, \& Sindrup, 2008); sentinel lymph node biopsy (SNLB) versus an axillary lymph node dissection (ALND) (Andersen, et al., 2013; Brar, Jain, \& Singh, 2011; Haid, et al., 2002; Langer, et al., 2007; Ronka, von Smitten, Tasmuth, \& Leidenius, 2005; Vilholm, et al., 2008); and following receipt of radiation therapy (RT) (Deutsch \& Flickinger, 2001; Hopwood, et al., 2010; Vilholm, et al., 2008). As noted by Andersen and Kehlet (2011), while the majority of studies reported no differences in arm pain between breast conserving surgery and mastectomy, these findings need to be interpreted with caution because the nociceptive effect of RT was not evaluated. In terms of SLNB versus ALND dissection, while inconsistent findings are noted in the literature, Andersen and Kehlet concluded that ALND is a risk factor for the development of persistent pain following breast cancer surgery.

Recently, our research group identified four subgroups of patients with distinct trajectories of persistent breast pain following breast cancer surgery (i.e., no (31.7\%), mild (43.4\%), moderate (13.3\%), and severe (11.6\%) pain) (Miaskowski, et al., 2012). These subgroups differed on a number of demographic, preoperative, intraoperative, and postoperative characteristics. As part of our longitudinal study, separate assessments of arm/shoulder pain were done monthly for six months following surgery. These separate assessments of arm/ shoulder versus breast pain were purposely designed to be comparable so that differences in 
persistent pain between the two distinct anatomic sites (e.g., different types of tissue at each site, different patterns of neural innervation) could be evaluated. Given that no studies were identified that evaluated for distinct subgroups and risk factors for persistent arm/shoulder pain following breast cancer surgery, the purposes of this prospective, longitudinal study, that recruited 398 women prior to surgery for breast cancer were to determine the prevalence of persistent pain in the arm/shoulder; characterize distinct persistent pain phenotype(s) using growth mixture modeling (GMM); and evaluate for differences among these pain classes in demographic, preoperative, intraoperative, and postoperative characteristics. In addition, differences in the severity of common symptoms and QOL outcomes measured prior to surgery, among the identified pain classes, were evaluated.

\section{METHODS}

A detailed description of the methods are published elsewhere (McCann, et al., 2012; Miaskowski, et al., 2012). In this section, an abbreviated version of the methods is described.

\section{Patients and Settings}

Patients were recruited from Breast Care Centers located in a Comprehensive Cancer Center, two public hospitals, and four community practices. Patients were eligible for this study if they were $\geq 18$ years of age; underwent surgery for cancer on one breast; were able to read, write, and understand English; agreed to participate, and provided written informed consent. Patients were excluded if they had surgery on both breasts and/or had distant metastasis at diagnosis. A total of 516 patients were approached to participate, 410 were enrolled in the study (response rate 79.4\%), and 398 completed the study questionnaires. The major reasons for refusal were: too busy, overwhelmed with the cancer diagnosis, or insufficient time available to do baseline assessment prior to surgery.

\section{Subjective Measures}

A demographic questionnaire collected information on age, education, ethnicity, marital status employment status, living situation, financial status and functional status (Karnofsky, 1977; Karnofsky, Abelmann, Craver, \& Burchenal, 1948). Comorbidities were assessed using the Self-Administered Comorbidity Questionnaire (SCQ) (Sangha, Stucki, Liang, Fossel, \& Katz, 2003).

Persistent and postsurgical pain were evaluated using the Arm/Shoulder Symptoms Questionnaire (ASQ) and Postsurgical Pain Questionnaire. The ASQ is an adaptation of the Brief Pain Inventory (BPI) (Daut, Cleeland, \& Flanery, 1983). The ASQ consisted of two parts. Part 1 obtained information on the occurrence of pain in the arm and shoulder area. If the patient had pain in the shoulder, arm, or hand, they completed Part 2 of the ASQ. Patients were asked to rate the intensity of their average and worst pain using a numeric rating scale (NRS) that ranged from 0 (no pain) to 10 (worst imaginable pain) (Jensen, 2003).

The Postsurgical Pain Questionnaire evaluated pain intensity, pain relief, and satisfaction with pain treatment in the first 24 to 48 hours after surgery. Average and worst pain were 
rated using a 0 to 10 NRS. Pain relief was rated on a $0 \%$ (no relief) to $100 \%$ (complete relief) rating scale. Satisfaction with pain treatment was rated on a 0 (not satisfied at all) to 10 (extremely satisfied) NRS. This questionnaire was completed during the month 1 study visit.

The Center for Epidemiologic Studies-Depression (CES-D) scale was used to evaluate depressive symptoms. A CES-D score of $\geq 16$ suggests the need for individuals to seek clinical evaluation for major depression (Carpenter, et al., 1998; Radloff, 1977; Sheehan, Fifield, Reisine, \& Tennen, 1995). The Spielberger State-Trait Anxiety Inventories (STAI-S and STAI-T) were used to evaluate state and trait anxiety. Cuttoff scores of $\geq 31.8$ and $\geq 32.2$ indicate high levels of trait and state anxiety, respectively (Bieling, Antony, \& Swinson, 1998; Kennedy, Schwab, Morris, \& Beldia, 2001; Spielberger, Gorsuch, Suchene, Vagg, \& Jacobs, 1983). The General Sleep Disturbance Scale (GSDS) was used to evaluate sleep disturbance in the past week. A GSDS total score of $\geq 43$ indicates a significant level of sleep disturbance (Carney, et al., 2011; Fletcher, et al., 2008; Garrett, et al., 2011; Miaskowski, et al., 2006). The Lee Fatigue Scale (LFS) was used to evaluate physical fatigue and energy (Lee, Hicks, \& Nino-Murcia, 1991). A cutoff score of $\geq 4.4$ indicates high levels of fatigue. (Dhruva, et al., 2010) A cutoff score of $\$ 4.8$ indicates low levels of energy (Dhruva, et al., 2010). The Attentional Function Index (AFI) was used to evaluate self-reported attentional function (i.e., ability to voluntarily direct and sustain attention) (Cimprich, 1992; Cimprich, Visovatti, \& Ronis, 2011). AFI scores can be grouped into categories of functional status (i.e., patients who score $<5.0$ functioning poorly, patients who score 5.0 to 7.5 functioning moderately well, patients who score $>7.5$ functioning well) (Cimprich, So, Ronis, \& Trask, 2005). The Quality of Life-Scale-Patient Version (QOL-PV) was used to evaluate four dimensions of QOL (i.e., physical well-being, psychological well-being, spiritual wellbeing, social well-being) as well as overall QOL. Higher scores indicating a better QOL (Ferrell, 1995; Ferrell, Dow, \& Grant, 1995; Padilla, Ferrell, Grant, \& Rhiner, 1990; Padilla, et al., 1983).

\section{Objective Measures}

Grip strength (in kilograms), in both hands, was measured using a Jamar hydraulic hand dynamometer (Sammons Preston). Grip strength was measured with women in a standing position with the arm held in a comfortable position (Spijkerman, Snijders, Stijnen, \& Lankhorst, 1991). Grip strength was measured three times in each hand. If a variance of more than $20 \%$ occurred among the three readings on each hand, the test was repeated. The three readings from the affected and unaffected hands were averaged(Ribom, Piehl-Aulin, Ljunghall, Ljunggren, \& Naessen, 2002; Spijkerman, et al., 1991).

Shoulder mobility was assessed using goniometric measurement of range of motion (ROM). While the patient was lying supine, ROM was measured twice on each side in four positions (i.e., flexion, abduction, internal rotation, external rotation) and these measurements were averaged. 


\section{Study Procedures}

The study was approved by the Committee on Human Research at the University of California, San Francisco and by the Institutional Review Boards at each of the study sites. During the patient's preoperative visit, a clinician explained the study to the patient, determined her willingness to participate, and introduced the patient to the research nurse. The research nurse determined eligibility and obtained written informed consent prior to surgery. After obtaining written informed consent, patients completed the enrollment questionnaires (Assessment 0 ). Following the completion of these questionnaires, the research nurse performed the objective measurements.

The research nurse met with the patients either in their home or in the Clinical Research Center at 1, 2, 3, 4, 5, and 6 months after surgery. During the study visits, the patients completed the study questionnaires, provided information on new and ongoing treatments, and had the objective measures done by the research nurse. Patients' medical records were reviewed for disease and treatment information.

\section{Statistical analyses}

Data were analyzed using SPSS Version 19.0(SPSS, 2010) and Mplus Version 6.11 (Muthen $\&$ Muthen, 1998-2010). Demographic and clinical characteristics and symptom severity scores were analyzed using descriptive statistics and frequency distributions.

Unconditional GMM with robust maximum likelihood estimation was carried out to identify latent classes of patients with distinct persistent arm pain trajectories. Arm/shoulder pain scores were assessed monthly for 6 months following breast cancer surgery. Prior to conducting GMM analyses, patients who reported no pain in their affected arm/shoulder for all 6 assessments were identified $(n=164,41.6 \%)$ and not included in the GMM analysis. The remaining 230 women's ratings of worst arm/shoulder pain were used in the GMM analysis. These methods are described in detail elsewhere (Dunn, et al., 2011). In brief, a single growth curve that represented the "average" change trajectory was estimated for the sample. Then, the number of latent growth classes that best fit the data was identified using guidelines recommended in the literature (T. Jung \& Wickrama, 2008; Nylund, Asparouhov, \& Muthen, 2007; Tofighi \& Enders, 2008).

Analyses of variance and Chi-square analyses were used to evaluate for differences, among the latent classes, in demographic, preoperative, intraoperative, and postoperative characteristics, symptom severity scores, and QOL scores at enrollment. Based on the recommendations of Rothman (1990), no adjustments were made for multiple testing. A pvalue of $<.05$ was considered statistically significant.

\section{RESULTS}

\section{GMM Analysis}

A total of 164 patients (41.6\%; no pain class) did not report any arm/shoulder pain for any of the six assessments. In the remaining 230 patients, two distinct latent classes of persistent arm/shoulder pain were identified using GMM (Figure 1). A two-class model was selected 
because its BIC was smaller than the three-class model. In addition, comparisons of the other fit indices supported the choice of the two class model (Table 1).

As shown in Table 2, the mild pain class $(\mathrm{n}=93,23.6 \%)$ maintained a similar level of pain throughout the study. Patients in the moderate pain class ( $\mathrm{n}=137,34.8 \%)$ had worst pain scores that decreased slightly to the month 4 assessment and then began to increase slightly during months 5 and 6 .

\section{Differences in Demographic Characteristics}

As shown in Table 3, no differences were found among the three pain classes in living arrangements, marital status, and employment status. However, patients in the mild and moderate pain classes were significantly younger than patients in the no pain class. In addition, patients in the moderate pain class were more likely to be non-White compared to the no and mild pain classes. Finally, patients in the moderate pain class reported a lower level of education and less income than patients in the mild pain class.

\section{Differences in Preoperative Clinical Characteristics}

A large number of significant differences among the three pain classes was found in the preoperative characteristics (Table 4). In general, compared to patients in the no pain class, patients in the moderate pain class had a higher body mass index (BMI), a lower KPS score; a higher SCQ score, a higher number of breast biopsies, higher ratings of average and worst breast pain prior to surgery; decreased flexion in their affected arm; a higher stage of disease; were more likely to report pain and swelling in their affected breast prior surgery, and were more like to have received neoadjuvant chemotherapy (CTX).

\section{Differences in Preoperative Symptom Severity Scores}

As shown in Table 5, significant differences in preoperative symptom severity scores were found among the pain classes. In general, compared to the no pain class, patients in the moderate pain class reported significantly higher depression, trait anxiety, sleep disturbance, and fatigue scores, and lower attentional function scores prior to surgery.

\section{Differences in Preoperative QOL Scores}

As shown in Table 5, significant differences in QOL scores were found among the pain classes. In general, compared to the no pain class, patients in the mild and moderate pain classes reported significantly lower physical well-being, social well-being, and total QOL scores prior to surgery.

\section{Differences in Intraoperative Characteristics}

As shown in Table 6, significant differences were found among the three pain classes for several of the intraoperative characteristics. Compared to patients in the no pain class, patients in the moderate pain class had a higher number of lymph nodes removed, a higher number of positive lymph nodes, and a higher number of drains placed during surgery. In addition compared to the no pain class, a higher percentage of patients in the moderate pain class had a mastectomy and an axillary lymph node dissection (ALND). 


\section{Differences in Postoperative Characteristics}

As shown in Table 7, significant differences in a number of postoperative characteristics were found among the three pain classes. Compared to the no pain class, patients in the moderate pain class experienced a higher number of postoperative complications; reported higher average and worst postoperative pain intensity scores, and were more likely to have had a surgical drain placed in the axilla or in the breast and axilla. In addition, compared to the no pain class, a higher percentage of patients in the moderate pain class had received physical therapy in the 6 months following breast cancer surgery.

\section{DISCUSSION}

This study is the first to use GMM to identify subgroups of patients with distinct persistent arm/shoulder pain trajectories following breast cancer surgery. In addition, a comprehensive list of demographic, preoperative, intraoperative, and postoperative characteristics was used to identify predictors of pain class membership. Over the six months of the study, $41.6 \%$ of the patients responded no to the question about having pain in their arm/shoulder. However, consistent with previous reports (Karki, Simonen, Malkia, \& Selfe, 2005; Tasmuth, von Smitten, Hietanen, Kataja, \& Kalso, 1995), 35\% of the patients were classified as having moderate pain. These patients had worst arm/shoulder pain scores of approximately 6 that remained relatively constant over the six months of the study. Of note, compared to our GMM analysis of persistent breast pain that identified three distinct breast pain classes (i.e., mild (43.4\%), moderate (13.3\%), and severe (11.6\%)) (Miaskowski, et al., 2012), only two persistent arm pain classes were identified. In addition, the percentage of women who did not report persistent arm/shoulder pain (i.e., 41.6\%) was higher than the percentage of women who did not report persistent breast pain (i.e., 31.7\%). These findings from the GMM analyses, as well differences in phenotypic characteristics discussed below, suggest that persistent breast pain and persistent arm/shoulder pain are distinct subtypes of persistent pain following breast cancer surgery.

Consistent with our previous study of persistent breast pain (Miaskowski, et al., 2012), four demographic characteristics, namely younger age, less education, being non-white, and having a lower total annual household income, were associated with being in the moderate pain class. Consistent with previous studies (Alves Nogueira Fabro, et al., 2012; Caffo, et al., 2003; Gartner, et al., 2009; Hack, Cohen, Katz, Robson, \& Goss, 1999; Macdonald, Bruce, Scott, Smith, \& Chambers, 2005; Peuckmann, et al., 2009; Poleshuck, et al., 2006; Smith, Bourne, Squair, Phillips, \& Chambers, 1999; Steegers, Wolters, Evers, Strobbe, \& Wilder-Smith, 2008; Swenson, et al., 2002; Vilholm, et al., 2008), younger age was associated with a higher risk of being in the mild or moderate pain classes identified in this study. While studies of racial/ethnic differences in experimental (Edwards, Doleys, Fillingim, \& Lowery, 2001) and clinical pain (Edwards, Moric, Husfeldt, Buvanendran, \& Ivankovich, 2005; Green, Ndao-Brumblay, Nagrant, Baker, \& Rothman, 2004) have produced inconsistent results, the higher percentage of non- whites in the moderate pain class is consistent with one other study of breast cancer patients (Fecho, et al., 2009). However, this finding should be interpreted with caution because compared to White patients, non-white patients in our study were more likely to be diagnosed with more 
advanced disease $(\mathrm{p}=.009)$ and to have had an ALND $(\mathrm{p}=.04)$ both of which may contribute to more severe pain. While lower levels of education (Krueger \& Stone, 2008; Portenoy, Ugarte, Fuller, \& Haas, 2004) and lower income levels (Cimmino, Ferrone, \& Cutolo, 2011; Palmlof, et al., 2012) are associated with higher rates of chronic pain in the general population, in two studies of persistent pain after breast cancer surgery (Kudel, et al., 2007; Poleshuck, et al., 2006), no association was found between education and pain status.

Compared to our previous study of persistent breast pain (Miaskowski, et al., 2012), several preoperative risk factors were unique to persistent arm/shoulder pain. Compared to patients in the no arm/shoulder pain class, patients in the moderate pain class had a higher number of breast biopsies, were diagnosed with more advanced disease, and were more likely to have received neoadjuvant CTX. These preoperative risk factors are consistent with a number of intraoperative characteristics that were associated with membership in the moderate pain class. Consistent with previous reports, two of the intraoperative characteristics associated with membership in the moderate pain class were a higher number of lymph nodes removed (Alves Nogueira Fabro, et al., 2012; Johansen, Overgaard, Blichert-Toft, \& Overgaard, 2000) and having an ALND (Alves Nogueira Fabro, et al., 2012; Caffo, et al., 2003; Gartner, et al., 2009). In addition, and distinct from predictors of persistent breast pain, patients in the moderate arm/shoulder pain class had a higher number of drains placed during surgery, were more likely to have a drain either in the axilla or in the breast and axilla, and to have a higher number of postoperative complications. Taken together these findings suggest that moderate, persistent arm/shoulder pain is more likely to occur in patients who have a surgical procedure that is associated with more trauma and inflammation.

Similar to persistent breast pain (Miaskowski, et al., 2012), two modifiable preoperative risk factors for persistent arm/shoulder pain were the occurrence of preoperative breast pain and changes in breast sensations. Women who reported the occurrence of pain or strange sensations in the breast were more likely to be classified into the moderate arm/shoulder pain class. Our results confirm the finding of a previous study (Kudel, et al., 2007) that found a relationship between preoperative breast pain and the occurrence of persistent pain following breast cancer surgery. However, research is warranted to determine additional risk factors for preoperative pain that may contribute to the development of persistent postsurgical pain. For example, we reported recently that variations in two cytokine genes (i.e., interleukin (IL) 1 receptor 1, IL13) were associated with the occurrence of preoperative breast pain (McCann, et al., 2012). Additional research is warranted on the mechanisms that underlie preoperative breast pain and its association with the development of persistent postsurgical pain in both the breast and/or the arm/shoulder.

A major modifiable risk factor for persistent arm/shoulder pain was unrelieved postoperative pain. Compared to the no pain class, ratings of worst postoperative pain were significantly higher in both the mild and moderate pain classes. These findings represent not only statistically significant differences but clinically meaningful differences in ratings of worst postoperative pain between the no pain versus the mild arm pain (d=.30) and the no pain versus the moderate pain $(\mathrm{d}=.87$ ) latent classes (Guyatt, Osoba, Wu, Wyrwich, \& Norman, 2002; Osoba, 1999; Osoba, Rodrigues, Myles, Zee, \& Pater, 1998). In addition, these 
findings are consistent with data from two retrospective studies (Steegers, et al., 2008; Tasmuth, et al., 1995), as well as our previous report of persistent breast pain (Miaskowski, et al., 2012), that found an association between higher postoperative pain scores and the development of persistent postsurgical pain. While detailed information is not available on the postoperative pain regimens that were ordered for the patients in our study, our data suggest that more effective postoperative pain management may reduce the occurrence of both persistent breast and arm/shoulder pain.

While the receipt of RT was associated with persistent breast pain in our previous study (Miaskowski, et al., 2012), it was not associated with persistent arm/shoulder pain. While it is well established that RT can cause neuropathic pain (B. F. Jung, Ahrendt, Oaklander, \& Dworkin, 2003), the location of the radiation field may impact the development of persistent pain following breast cancer surgery (Andersen \& Kehlet, 2011). In this study, detailed information was not obtained on the location of the radiation field. Therefore, patients cannot be subdivided into specific groups based on the location of RT (e.g., residual breast, chest wall, axilla).

It is interesting to note that a higher percentage of patients in the moderate pain group had received physical therapy during the six months following breast cancer surgery. The specific reason for the physical therapy consultation was not obtained as part of the patients' assessments. Patients could be referred to physical therapy for limitations in shoulder mobility that is associated with scar tissue formation after an ALND and/or lymphedema. Fear of exacerbating the pain associated with scar tissue formation and/or lymphedema prevents women from using their arm/shoulder which results in contractures and more pain. Because the rehabilitation exercises could contribute to increased pain in these patients, preemptive pain management strategies should be used during physical therapy. Future studies need to evaluate the association between pain and physical therapy in more detail.

Consistent with our previous study of persistent breast pain (Miaskowski, et al., 2012), patients classified in the moderate arm/shoulder pain class reported higher preoperative levels of depressive symptoms, trait anxiety, sleep disturbance, fatigue, and lower levels of attentional function. Of note, except for state anxiety $(\mathrm{d}=.18)$, all of the differences in symptom severity scores between the no pain and moderate arm pain classes represent clinically meaningful differences in depression $(\mathrm{d}=.29)$, trait anxiety $(\mathrm{d}=.33)$, fatigue $(\mathrm{d}=$. 46), energy ( $\mathrm{d}=.24)$, sleep disturbance $(\mathrm{d}=.48)$ and attentional function $(\mathrm{d}=.41)$. These findings highlight the importance of addressing multiple concurrent symptoms that may worsen pain and have a negative impact on patients' QOL.

Additional research is warranted to identify specific risk factors for the development of persistent breast (Miaskowski, et al., 2012) versus persistent arm/shoulder pain. In this study, only $20 \%$ of the patients were classified in both the no breast and no arm/shoulder pain GMM groups. In contrast, only $7.9 \%$ of the patients were classified in both the severe breast and moderate arm/shoulder pain groups. This finding suggests that different factors and/or mechanisms may be associated with persistent pain in different locations following breast cancer surgery. Detailed evaluation of phenotypic characteristics for and molecular markers of persistent pain at each site may provide insights into potential pain mechanisms. 
Several study limitations need to be acknowledged. While the sample size was adequate, additional latent classes may be identified with a larger sample. While the sample was representative of breast cancer patients in the United States, different latent classes and/or different risk factors may have been identified if a larger percentage of the sample was nonWhite, older, had more advanced disease, and/or required more extensive surgery. To increase the generalizability of the study findings, patients were recruited through referrals from twenty surgeons at seven different sites. Future studies need to evaluate how differences in surgical protocols, as well as postoperative pain management protocols influence the development of persistent arm/shoulder pain. In addition, future studies need to evaluate postoperative pain scores in a prospective manner rather than rely on patient recall. In our previous paper on persistent breast pain (Miaskowski, et al., 2012), a detailed evaluation of analgesic use was reported. Since the majority of these women were not prescribed analgesics over the six months of the study, a separate analysis of analgesic use for persistent arm/shoulder pain was not performed.

In conclusion, this study is one of the largest, prospective, longitudinal studies to evaluate the prevalence of and risk factors for persistent arm/shoulder pain following breast cancer surgery and to compare these findings with risk factors for persistent breast pain (Miaskowski, et al., 2012). Future analyses are focused on determining the specific pain characteristics for the two arm/shoulder pain classes identified using GMM as well as genomic predictors of latent class membership.

\section{Acknowledgments}

Funding source: This study was funded by grants from the National Cancer Institute (CA107091 and CA118658). Dr. Bradley Aouizerat was funded through the National Institutes of Health (NIH) Roadmap for Medical Research Grant (KL2 RR624130). Dr. Dunn received funding from the Mount Zion Health Fund. Dr. Christine Miaskowski is an American Cancer Society Clinical Research Professor. Dr. Dhruva is funded through NIH Mentored PatientOriented Research Career Development Award (K23 AT005340). Dr. Langford is supported by a Department of Defense Breast Cancer Research Program Postdoctoral Fellowship. Dr. Merriman was supported by an NINR fellowship (F31 NR012604), an ACS Doctoral Degree Scholarship (DSCN-10-087), an Oncology Nursing Foundation Doctoral Scholarship, and a UCSF Nursing Alumni Association Scholarship. Dr. Baggott is funded by an American Cancer Society Mentored Research Scholar Award (MRSG 12-01-PCSM). This project is supported by NIH/NCRR UCSF-CTSI Grant Number UL1 RR024131. Its contents are solely the responsibility of the authors and do not necessarily represent the official views of the NIH.

\section{REFERENCES}

Alves Nogueira Fabro E, Bergmann A, do Amaral ESB, Padula Ribeiro AC, de Souza Abrahao K, da Costa Leite Ferreira MG, et al. Post-mastectomy pain syndrome: Incidence and risks. Breast. 2012; 21(3):321-325. [PubMed: 22377590]

Andersen KG, Jensen MB, Tvedskov TF, Kehlet H, Gartner R, Kroman N. Persistent pain, sensory disturbances and functional impairment after immediate or delayed axillary lymph node dissection. European Journal of Surgical Oncology. 2013; 39(1):31-35. [PubMed: 23107434]

Andersen KG, Kehlet H. Persistent pain after breast cancer treatment: a critical review of risk factors and strategies for prevention. Journal of Pain. 2011; 12(7):725-746. [PubMed: 21435953]

Belfer I, Schreiber KL, Shaffer JR, Shnol H, Blaney K, Morando A, et al. Persistent postmastectomy pain in breast cancer survivors: analysis of clinical, demographic, and psychosocial factors. Journal of Pain. 2013; 14(10):1185-1195. [PubMed: 23890847]

Bieling PJ, Antony MM, Swinson RP. The State-Trait Anxiety Inventory, Trait version: structure and content re-examined. Behavioral Research and Therapy. 1998; 36(7-8):777-788. 
Brar P, Jain S, Singh I. Complications of axillary lymph node dissection in treatment of early breast cancer: A comparison of MRM and BCS. Indian Journal of Surgical Oncology. 2011; 2(2):126-132. [PubMed: 22693405]

Caffo O, Amichetti M, Ferro A, Lucenti A, Valduga F, Galligioni E. Pain and quality of life after surgery for breast cancer. Breast Cancer Research and Treatment. 2003; 80(1):39-48. [PubMed: 12889597]

Carney S, Koetters T, Cho M, West C, Paul SM, Dunn L, et al. Differences in sleep disturbance parameters between oncology outpatients and their family caregivers. Journal of Clinical Oncology. 2011; 9(8):1001-1006. [PubMed: 21282549]

Carpenter JS, Andrykowski MA, Wilson J, Hall LA, Rayens MK, Sachs B, et al. Psychometrics for two short forms of the Center for Epidemiologic Studies-Depression Scale. Issues Mental Health Nursing. 1998; 19(5):481-494.

Carpenter JS, Sloan P, Andrykowski MA, McGrath P, Sloan D, Rexford T, et al. Risk factors for pain after mastectomy/lumpectomy. Cancer Practice. 1999; 7(2):66-70. [PubMed: 10352063]

Cimmino MA, Ferrone C, Cutolo M. Epidemiology of chronic musculoskeletal pain. Best Practice and Research in Clinical Rheumatology. 2011; 25(2):173-183.

Cimprich B. Attentional fatigue following breast cancer surgery. Research in Nursing and Health. 1992; 15(3):199-207. [PubMed: 1354883]

Cimprich B, So H, Ronis DL, Trask C. Pre-treatment factors related to cognitive functioning in women newly diagnosed with breast cancer. Psychooncology. 2005; 14(1):70-78. [PubMed: 15386786]

Cimprich B, Visovatti M, Ronis DL. The Attentional Function Index--a self-report cognitive measure. Psychooncology. 2011; 20(2):194-202. [PubMed: 20213858]

Daut RL, Cleeland CS, Flanery RC. Development of the Wisconsin Brief Pain Questionnaire to assess pain in cancer and other diseases. Pain. 1983; 17(2):197-210. [PubMed: 6646795]

Deutsch M, Flickinger JC. Shoulder and arm problems after radiotherapy for primary breast cancer. American Journal of Clinical Oncology. 2001; 24(2):172-176. [PubMed: 11319294]

Dhruva A, Dodd M, Paul SM, Cooper BA, Lee K, West C, et al. Trajectories of fatigue in patients with breast cancer before, during, and after radiation therapy. Cancer Nursing. 2010; 33(3):201-212. [PubMed: 20357659]

Dunn LB, Cooper BA, Neuhaus J, West C, Paul S, Aouizerat B, et al. Identification of distinct depressive symptom trajectories in women following surgery for breast cancer. Health Psychology. 2011; 30(6):683-692. [PubMed: 21728421]

Edwards RR, Doleys DM, Fillingim RB, Lowery D. Ethnic differences in pain tolerance: clinical implications in a chronic pain population. Psychosomatic Medicine. 2001; 63(2):316-323. [PubMed: 11292281]

Edwards RR, Moric M, Husfeldt B, Buvanendran A, Ivankovich O. Ethnic similarities and differences in the chronic pain experience: a comparison of African American, Hispanic, and White patients. Pain Medicine. 2005; 6(1):88-98. [PubMed: 15669954]

Fecho K, Miller NR, Merritt SA, Klauber-Demore N, Hultman CS, Blau WS. Acute and persistent postoperative pain after breast surgery. Pain Medicine. 2009; 10(4):708-715. [PubMed: 19453965]

Ferrell BR. The impact of pain on quality of life. A decade of research. Nursing Clinics of North America. 1995; 30(4):609-624. [PubMed: 7501531]

Ferrell BR, Dow KH, Grant M. Measurement of the quality of life in cancer survivors. Quality of Life Research. 1995; 4(6):523-531. [PubMed: 8556012]

Fletcher BS, Paul SM, Dodd MJ, Schumacher K, West C, Cooper B, et al. Prevalence, severity, and impact of symptoms on female family caregivers of patients at the initiation of radiation therapy for prostate cancer. Journal of Clinical Oncology. 2008; 26(4):599-605. [PubMed: 18235118]

Garrett K, Dhruva A, Koetters T, West C, Paul SM, Dunn LB, et al. Differences in sleep disturbance and fatigue between patients with breast and prostate cancer at the initiation of radiation therapy. Journal of Pain and Symptom Management. 2011; 42(2):239-250. [PubMed: 21454042]

Gartner R, Jensen MB, Nielsen J, Ewertz M, Kroman N, Kehlet H. Prevalence of and factors associated with persistent pain following breast cancer surgery. Journal of the American Medical Association. 2009; 302(18):1985-1992. [PubMed: 19903919] 
Green CR, Ndao-Brumblay SK, Nagrant AM, Baker TA, Rothman E. Race, age, and gender influences among clusters of African American and white patients with chronic pain. Journal of Pain. 2004; 5(3):171-182. [PubMed: 15106130]

Guyatt GH, Osoba D, Wu AW, Wyrwich KW, Norman GR. Methods to explain the clinical significance of health status measures. Mayo Clinic Proceedings. 2002; 77(4):371-383. [PubMed: 11936935]

Hack TF, Cohen L, Katz J, Robson LS, Goss P. Physical and psychological morbidity after axillary lymph node dissection for breast cancer. Journal of Clinical Oncology. 1999; 17(1):143-149. [PubMed: 10458227]

Haid A, Koberle-Wuhrer R, Knauer M, Burtscher J, Fritzsche H, Peschina W, et al. Morbidity of breast cancer patients following complete axillary dissection or sentinel node biopsy only: a comparative evaluation. Breast Cancer Research and Treatment. 2002; 73(1):31-36. [PubMed: 12083629]

Hopwood P, Haviland JS, Sumo G, Mills J, Bliss JM, Yarnold JR, et al. Comparison of patientreported breast, arm, and shoulder symptoms and body image after radiotherapy for early breast cancer: 5-year follow-up in the randomised Standardisation of Breast Radiotherapy (START) trials. Lancet Oncology. 2010; 11(3):231-240. [PubMed: 20138809]

Jensen MP. The validity and reliability of pain measures in adults with cancer. Journal of Pain. 2003; 4(1):2-21. [PubMed: 14622723]

Johansen J, Overgaard J, Blichert-Toft M, Overgaard M. Treatment of morbidity associated with the management of the axilla in breast-conserving therapy. Acta Oncology. 2000; 39(3):349-354.

Jung BF, Ahrendt GM, Oaklander AL, Dworkin RH. Neuropathic pain following breast cancer surgery: proposed classification and research update. Pain. 2003; 104(1-2):1-13. [PubMed: 12855309]

Jung T, Wickrama KAS. An introduction to latent class growth analysis and growth mixture modeling. Social and Personality Psychology Compass. 2008; 2(1):302-317.

Karki A, Simonen R, Malkia E, Selfe J. Impairments, activity limitations and participation restrictions 6 and 12 months after breast cancer operation. Journal of Rehabilitation Medicine. 2005; 37(3): 180-188. [PubMed: 16040476]

Karnofsky, D. Performance scale. Plenum Press; New York: 1977.

Karnofsky D, Abelmann WH, Craver LV, Burchenal JH. The use of nitrogen mustards in the palliative treatment of carcinoma. Cancer. 1948; 1:634-656.

Kennedy BL, Schwab JJ, Morris RL, Beldia G. Assessment of state and trait anxiety in subjects with anxiety and depressive disorders. Psychiatric Quarterly. 2001; 72(3):263-276. [PubMed: 11467160]

Krueger AB, Stone AA. Assessment of pain: a community-based diary survey in the USA. Lancet. 2008; 371(9623):1519-1525. [PubMed: 18456101]

Kudel I, Edwards RR, Kozachik S, Block BM, Agarwal S, Heinberg LJ, et al. Predictors and consequences of multiple persistent postmastectomy pains. Journal of Pain and Symptom Management. 2007; 34(6):619-627. [PubMed: 17629668]

Langer I, Guller U, Berclaz G, Koechli OR, Schaer G, Fehr MK, et al. Morbidity of sentinel lymph node biopsy (SLN) alone versus SLN and completion axillary lymph node dissection after breast cancer surgery: a prospective Swiss multicenter study on 659 patients. Annals of Surgery. 2007; 245(3):452-461. [PubMed: 17435553]

Lee KA, Hicks G, Nino-Murcia G. Validity and reliability of a scale to assess fatigue. Psychiatry Research. 1991; 36(3):291-298. [PubMed: 2062970]

Macdonald L, Bruce J, Scott NW, Smith WC, Chambers WA. Long-term follow-up of breast cancer survivors with post-mastectomy pain syndrome. British Journal of Cancer. 2005; 92(2):225-230. [PubMed: 15655557]

McCann B, Miaskowski C, Koetters T, Baggott C, West C, Levine JD, et al. Associations between pro- and anti-inflammatory cytokine genes and breast pain in women prior to breast cancer surgery. Journal of Pain. 2012; 13(5):425-437. [PubMed: 22515947] 
Miaskowski C, Cooper B, Paul SM, West C, Langford D, Levine JD, et al. Identification of patient subgroups and risk factors for persistent breast pain following breast cancer surgery. Journal of Pain. 2012; 13(12):1172-1187. [PubMed: 23182226]

Miaskowski C, Cooper BA, Paul SM, Dodd M, Lee K, Aouizerat BE, et al. Subgroups of patients with cancer with different symptom experiences and quality-of-life outcomes: a cluster analysis. Oncology Nursing Forum. 2006; 33(5):E79-89. [PubMed: 16955115]

Muthen, LK.; Muthen, BO. Mplus User's Guide. 6th. Muthen \& Muthen; Los Angeles, CA: 1998-2010.

Nesvold IL, Dahl AA, Lokkevik E, Marit Mengshoel A, Fossa SD. Arm and shoulder morbidity in breast cancer patients after breast-conserving therapy versus mastectomy. Acta Oncology. 2008; 47(5):835-842.

Nylund KL, Asparouhov T, Muthen BO. Deciding on the number of classes in latent class analysis and growth mixture modeling: A Monte Carlo simulation study. Structural Equation Modeling. 2007; 14(4):535-569.

Osoba D. Interpreting the meaningfulness of changes in health-related quality of life scores: lessons from studies in adults. International Journal of Cancer. 1999; (Supplement 12):132-137. [PubMed: 10679884]

Osoba D, Rodrigues G, Myles J, Zee B, Pater J. Interpreting the significance of changes in healthrelated quality-of-life scores. Journal of Clinical Oncology. 1998; 16(1):139-144. [PubMed: 9440735]

Padilla GV, Ferrell B, Grant MM, Rhiner M. Defining the content domain of quality of life for cancer patients with pain. Cancer Nursing. 1990; 13(2):108-115. [PubMed: 2331691]

Padilla GV, Presant C, Grant MM, Metter G, Lipsett J, Heide F. Quality of life index for patients with cancer. Research in Nursing and Health. 1983; 6(3):117-126. [PubMed: 6556698]

Palmlof L, Skillgate E, Alfredsson L, Vingard E, Magnusson C, Lundberg M, et al. Does income matter for troublesome neck pain? A population-based study on risk and prognosis. Journal of Epidemiology and Community Health. 2012; 66(11):1063-1070. [PubMed: 22412154]

Peuckmann V, Ekholm O, Rasmussen NK, Groenvold M, Christiansen P, Moller S, et al. Chronic pain and other sequelae in long-term breast cancer survivors: nationwide survey in Denmark. European Journal of Pain. 2009; 13(5):478-485. [PubMed: 18635381]

Poleshuck EL, Katz J, Andrus CH, Hogan LA, Jung BF, Kulick DI, et al. Risk factors for chronic pain following breast cancer surgery: a prospective study. Journal of Pain. 2006; 7(9):626-634. [PubMed: 16942948]

Portenoy RK, Ugarte C, Fuller I, Haas G. Population-based survey of pain in the United States: differences among white, African American, and Hispanic subjects. Journal of Pain. 2004; 5(6): 317-328. [PubMed: 15336636]

Radloff LS. The CES-D Scale: A self-report depression scale for research in the general population. Applied Psychological Measurement. 1977; 1(3):385-401.

Ribom EL, Piehl-Aulin K, Ljunghall S, Ljunggren O, Naessen T. Six months of hormone replacement therapy does not influence muscle strength in postmenopausal women. Maturitas. 2002; 42(3): 225-231. [PubMed: 12161047]

Ronka R, von Smitten K, Tasmuth T, Leidenius M. One-year morbidity after sentinel node biopsy and breast surgery. Breast. 2005; 14(1):28-36. [PubMed: 15695078]

Rothman KJ. No adjustments are needed for multiple comparisons. Epidemiology. 1990; 1(1):43-46. [PubMed: 2081237]

Sangha O, Stucki G, Liang MH, Fossel AH, Katz JN. The Self-Administered Comorbidity Questionnaire: a new method to assess comorbidity for clinical and health services research. Arthritis and Rheumatism. 2003; 49(2):156-163. [PubMed: 12687505]

Sheehan TJ, Fifield J, Reisine S, Tennen H. The measurement structure of the Center for Epidemiologic Studies Depression Scale. Journal of Personality Assessment. 1995; 64(3):507521. [PubMed: 7760258]

Smith WC, Bourne D, Squair J, Phillips DO, Chambers WA. A retrospective cohort study of post mastectomy pain syndrome. Pain. 1999; 83(1):91-95. [PubMed: 10506676] 
Spielberger, CG.; Gorsuch, RL.; Suchene, R.; Vagg, PR.; Jacobs, GA. Manual for the State-Anxiety (Form Y): Self Evaluation Questionnaire. Consulting Psychologists Press; Palo Alto, CA: 1983.

Spijkerman DC, Snijders CJ, Stijnen T, Lankhorst GJ. Standardization of grip strength measurements. Effects on repeatability and peak force. Scandinavian Journal of Rehabilitation Medicine. 1991; 23(4):203-206. [PubMed: 1785029]

SPSS. IBM SPSS for Windows (Version 19). SPSS, Inc; Chicago, Illinois: 2010.

Steegers MA, Wolters B, Evers AW, Strobbe L, Wilder-Smith OH. Effect of axillary lymph node dissection on prevalence and intensity of chronic and phantom pain after breast cancer surgery. Journal of Pain. 2008; 9(9):813-822. [PubMed: 18585963]

Stevens PE, Dibble SL, Miaskowski C. Prevalence, characteristics, and impact of postmastectomy pain syndrome: an investigation of women's experiences. Pain. 1995; 61(1):61-68. [PubMed: 7644250]

Swenson KK, Nissen MJ, Ceronsky C, Swenson L, Lee MW, Tuttle TM. Comparison of side effects between sentinel lymph node and axillary lymph node dissection for breast cancer. Annals of Surgical Oncology. 2002; 9(8):745-753. [PubMed: 12374657]

Tasmuth T, von Smitten K, Hietanen P, Kataja M, Kalso E. Pain and other symptoms after different treatment modalities of breast cancer. Annals of Oncology. 1995; 6(5):453-459. [PubMed: 7669710]

Tasmuth T, von Smitten K, Kalso E. Pain and other symptoms during the first year after radical and conservative surgery for breast cancer. British Journal of Cancer. 1996; 74(12):2024-2031. [PubMed: 8980408]

Tofighi, D.; Enders, CK. Identifying the correct number of classes in growth mixture models. Information Age Publishing; Charlotte, NC: 2008.

Vilholm OJ, Cold S, Rasmussen L, Sindrup SH. The postmastectomy pain syndrome: an epidemiological study on the prevalence of chronic pain after surgery for breast cancer. British Journal of Cancer. 2008; 99(4):604-610. [PubMed: 18682712] 


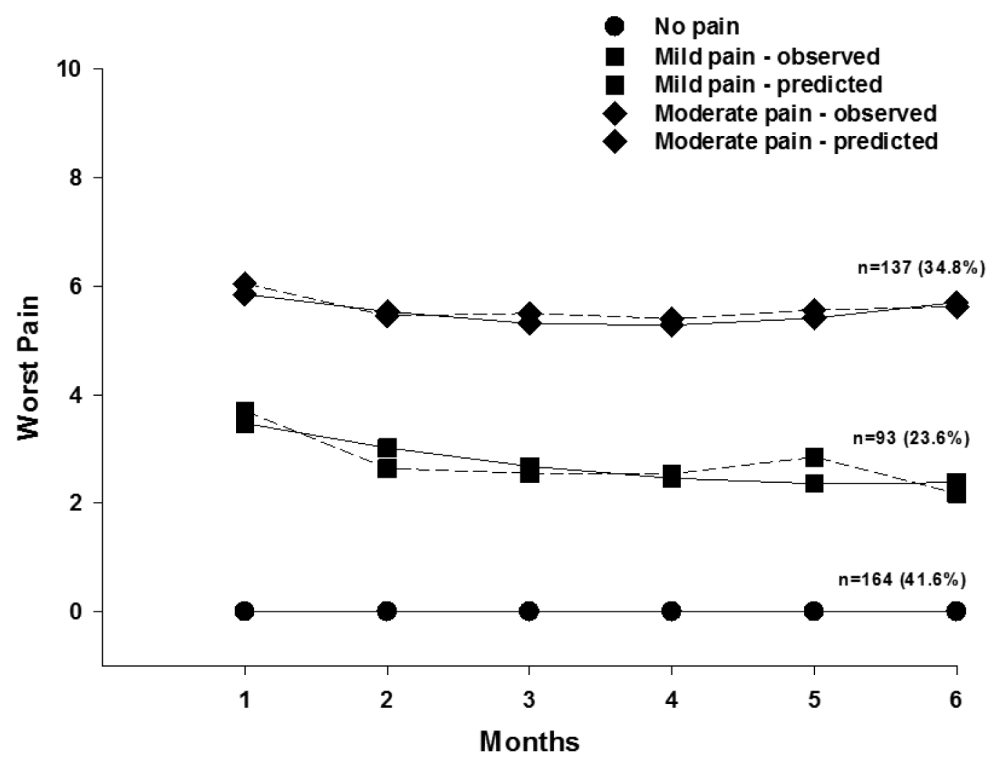

Figure 1.

Observed and estimated breast pain trajectories for patients in each of the latent classes. 


\section{Table 1}

Fit Indices for the Growth Mixture Model Class Solutions for the Severity of Worst Arm/Shoulder Pain

\begin{tabular}{lcccccc}
\hline GMM Solution & LL & AlC & BIC & Entropy & VLMR (df) & BLRT(df) \\
\hline 1-Class $^{a}$ & -1218.56 & 2457.12 & 2491.50 & N/A & N/A & N/A \\
2-Class $b$ & -1207.38 & 2442.75 & 2490.88 & .46 & $22.37^{n s}(4)$ & $22.37^{\dagger}(4)$ \\
3-Class & -1201.79 & 2441.59 & 2506.91 & .56 & $11.08^{n s}(4)$ & $11.08^{n s}(4)$ \\
\hline
\end{tabular}

Abbreviations: $\mathrm{AlC}=$ Akaike Information Criterion; $\mathrm{BIC}=$ Bayesian Information Criterion; BLRT = parametric bootstrapped likelihood ratio test for K-1 (HO) vs K classes; CFI = Comparative Fit Index; df = degrees of freedom; GMM = Growth mixture model; LL = loglikelihood; N/A = not applicable; RMSEA = Root Mean Squared Error of Approximation; VLMR = Vuong-Lo-Mendell-Rubin likelihood ratio test for K-1 (HO) vs K classes.

$n s$ not significant;

$\dagger_{\mathrm{p}}<0005$

${ }^{a}$ Latent growth curve model with linear and quadratic components; $\mathrm{Chi}^{2}=19.71,17 \mathrm{df}, \mathrm{p}=.29, \mathrm{CFI}=0.98, \mathrm{RMSEA}=.03$.

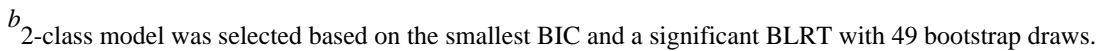




\section{Table 2}

Parameter Estimates for Predicted Growtii Mixture Model Latent Classes from Six Assessments of Ratings of the Severity of Worst Arm/Shoulder Pain

\begin{tabular}{ccc}
\hline & Class 1 & Class 2 \\
Parameter Estimates $^{b}$ & $\mathbf{N = 9 3}$ & $\mathbf{N = 1 3 7}$ \\
& $\mathbf{( 4 0 . 4 \% )}$ & $\mathbf{( 5 9 . 6 \% )}$ \\
\cline { 2 - 3 } & Mean (S.E.) & Mean (S.E.) \\
\hline Intercept & $3.48^{\dagger}(.38)$ & $5.85^{\dagger}(.37)$ \\
Linear slope & $-0.52^{*}(.26)$ & $-0.43^{*}(.21)$ \\
Quadratic slope & $0.06^{\text {ns }}(.06)$ & $0.08^{*}(.04)$ \\
Variances & & \\
Intercept & & \\
Linear slope & $0^{c}$ & $2.93^{\dagger}(.53)$ \\
Quadratic slope & $0^{c}$ & $0^{c}$ \\
\hline
\end{tabular}

Abbreviations: $\mathrm{ns}=$ not significant; GMM = growth mixture model; S.E. $=$ standard error

p ${ }^{*}<.05$

${ }^{\dagger} \mathrm{P}<.0005$

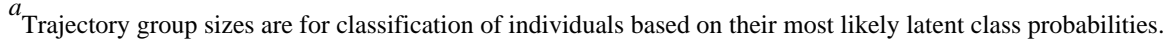

${ }^{b}$ GMM estimates were obtained with robust maximum likelihood.

${ }^{c}$ GMM could not be fit without fixing linear and quadratic slope variances to zero to allow model convergence. 
Table 3

Differences in Demograpiiic Ciiaracteristics Among the Arm/Siioulder Pain Classes

\begin{tabular}{|c|c|c|c|c|}
\hline \multirow[t]{2}{*}{ Characteristic } & $\begin{array}{l}\text { No Pain (0) } \\
164(41.6 \%)\end{array}$ & $\begin{array}{l}\text { Mild Pain (1) } \\
93(23.6 \%)\end{array}$ & $\begin{array}{c}\text { Moderate Pain (2) } \\
137(34.8 \%)\end{array}$ & \multirow[t]{2}{*}{ Statistics } \\
\hline & Mean (SD) & Mean (SD) & Mean (SD) & \\
\hline Age (years) & $58.0(12.1)$ & $52.7(9.7)$ & $52.9(11.3)$ & $\begin{array}{c}\mathrm{F}=10.07, \mathrm{p}<.0001 \\
0>1 \text { and } 2\end{array}$ \\
\hline \multirow[t]{2}{*}{ Education (years) } & $15.6(2.6)$ & $16.3(2.7)$ & $15.3(2.7)$ & $\begin{array}{c}\mathrm{F}=3.70, \mathrm{p}=.026 \\
1>2\end{array}$ \\
\hline & $\%(\mathrm{~N})$ & $\%(\mathrm{~N})$ & $\%(\mathrm{~N})$ & \\
\hline $\begin{array}{l}\text { Ethnicity } \\
\text { White } \\
\text { Non-white* }\end{array}$ & $\begin{array}{l}75.5(123) \\
24.5(40)\end{array}$ & $\begin{array}{l}68.8(64) \\
31.2(29)\end{array}$ & $\begin{array}{l}50.0(68) \\
50.0(68)\end{array}$ & $\begin{array}{c}\mathrm{X}^{2}=21.90, \mathrm{p}<.0001 \\
0 \text { and } 1<2\end{array}$ \\
\hline $\begin{array}{l}\text { Lives alone } \\
\text { Yes } \\
\text { No }\end{array}$ & $\begin{array}{l}25.3(41) \\
74.7(121)\end{array}$ & $\begin{array}{l}19.4(18) \\
80.6(75)\end{array}$ & $\begin{array}{l}24.6(33) \\
75.4(101)\end{array}$ & NS \\
\hline $\begin{array}{l}\text { Marital status } \\
\text { Married/partnered } \\
\text { Single, separated, widowed, divorced }\end{array}$ & $\begin{array}{l}43.2(70) \\
56.8(92)\end{array}$ & $\begin{array}{l}35.5(33) \\
64.5(60)\end{array}$ & $\begin{array}{l}43.0(58) \\
57.0(77)\end{array}$ & NS \\
\hline $\begin{array}{l}\text { Currently working for pay } \\
\text { Yes } \\
\text { No }\end{array}$ & $\begin{array}{l}49.4(80) \\
50.6(82)\end{array}$ & $\begin{array}{l}53.3(49) \\
46.7(43)\end{array}$ & $\begin{array}{l}43.1(59) \\
56.9(78)\end{array}$ & NS \\
\hline $\begin{array}{l}\text { Total annual household income } \\
<\$ 10,000 \text { to } \$ 19,999 \\
\$ 20,000 \text { to } \$ 99,000 \\
>\$ 100,000\end{array}$ & $\begin{array}{l}12.5(17) \\
47.1(64) \\
40.4(55)\end{array}$ & $\begin{array}{l}14.5(12) \\
38.6(32) \\
47.0(39)\end{array}$ & $\begin{array}{l}20.6(22) \\
51.4(55) \\
28.0(30)\end{array}$ & $\begin{array}{c}\mathrm{KW}, \mathrm{p}=.020 \\
1>2\end{array}$ \\
\hline
\end{tabular}

Abbreviations: $\mathrm{KW}=$ Kruskal Wallis; $\mathrm{NS}=$ Not significant 
Table 4

Differences in Preoperative Clinical Characteristics Among the Arm/Shoulder Pain Classes

\begin{tabular}{|c|c|c|c|c|}
\hline \multirow[t]{2}{*}{ Characteristic } & $\begin{array}{l}\text { No Pain (0) } \\
164(41.6 \%)\end{array}$ & $\begin{array}{c}\text { Mild Pain (1) } 93 \\
\quad(23.6 \%)\end{array}$ & $\begin{array}{c}\text { Moderate Pain (2) } \\
\quad 137(34.8 \%)\end{array}$ & \multirow[t]{2}{*}{ Statistics } \\
\hline & Mean (SD) & Mean (SD) & Mean (SD) & \\
\hline Body mass index $\left(\mathrm{kg} / \mathrm{m}^{2}\right)$ & $26.1(5.2)$ & $26.3(6.2)$ & $28.1(6.9)$ & $\begin{array}{c}\mathrm{F}=4.43, \mathrm{p}=.013 \\
0<2\end{array}$ \\
\hline Karnofsky Performance Status score & $96.7(6.8)$ & $93.1(10.0)$ & $89.3(12.4)$ & $\begin{array}{c}\mathrm{F}=21.50, \mathrm{p}<.0001 \\
0>1 \text { and } 2 ; 1>2\end{array}$ \\
\hline Self-Administered Comorbidity Scale score & $3.9(2.7)$ & $3.8(2.3)$ & $5.0(3.1)$ & $\begin{array}{c}\mathrm{F}=6.90, \mathrm{p}=.001 \\
0 \text { and } 1<2\end{array}$ \\
\hline Number of breast biopsies & $1.3(0.6)$ & $1.6(0.9)$ & $1.6(0.9)$ & $\begin{array}{c}\mathrm{F}=6.66, \mathrm{p}=.001 \\
0<1 \text { and } 2\end{array}$ \\
\hline Average breast pain & $0.3(1.1)$ & $0.5(1.0)$ & $0.9(1.9)$ & $\begin{array}{c}\mathrm{F}=7.56, \mathrm{p}=.001 \\
0<2\end{array}$ \\
\hline Worst breast pain & $0.4(1.4)$ & $1.0(1.6)$ & $1.5(2.6)$ & $\begin{array}{c}\mathrm{F}=10.90, \mathrm{p}<.0001 \\
0<2\end{array}$ \\
\hline Number of breast symptoms & $0.5(0.8)$ & $0.7(1.0)$ & $0.9(1.2)$ & $\begin{array}{c}\mathrm{F}=6.09, \mathrm{p}=.003 \\
0<2\end{array}$ \\
\hline Grip strength - unaffected hand $(\mathrm{kg})$ & $23.6(5.6)$ & $24.2(5.4)$ & $23.6(6.3)$ & NS \\
\hline Grip strength - affected hand $(\mathrm{kg})$ & $23.5(5.2)$ & $23.9(5.3)$ & $22.9(6.2)$ & NS \\
\hline Flexion -unaffected arm & $166.8(8.4)$ & $167.9(8.6)$ & $165.2(11.3)$ & NS \\
\hline Flexion - affected arm & $166.3(9.6)$ & $167.7(8.9)$ & $163.0(12.3)$ & $\begin{array}{c}\mathrm{F}=6.12, \mathrm{p}=.002 \\
0 \text { and } 1>2\end{array}$ \\
\hline Abduction - unaffected arm & $149.9(17.1)$ & $154.9(16.8)$ & $147.7(20.2)$ & $\begin{array}{c}\mathrm{F}=4.32, \mathrm{p}=.014 \\
1>2\end{array}$ \\
\hline Abduction - affected arm & $149.2(18.6)$ & $154.4(17.4)$ & $144.8(24.1)$ & $\begin{array}{c}\mathrm{F}=6.05, \mathrm{p}=.003 \\
1>2\end{array}$ \\
\hline Internal rotation - unaffected arm & $63.2(8.1)$ & $62.8(9.1)$ & $63.4(8.5)$ & NS \\
\hline Internal rotation - affected arm & $62.7(8.5)$ & $63.5(8.9)$ & $62.5(9.4)$ & NS \\
\hline External rotation - unaffected arm & $79.3(7.4)$ & $80.7(6.6)$ & $78.3(9.1)$ & NS \\
\hline \multirow[t]{2}{*}{ External rotation - affected arm } & $79.3(7.6)$ & $80.5(7.1)$ & $76.9(10.4)$ & $\begin{array}{c}\mathrm{F}=5.64, \mathrm{p}=.004 \\
0 \text { and } 1>2\end{array}$ \\
\hline & $\%(\mathrm{~N})$ & $\%(\mathrm{~N})$ & $\%(\mathrm{~N})$ & \\
\hline $\begin{array}{l}\text { Occurrence of comorbid conditions (\% and number of } \\
\text { women who reported each comorbid condition from } \\
\text { the Self-Administered Comorbidity Questionnaire) } \\
\text { Heart disease } \\
\text { High blood pressure } \\
\text { Lung disease } \\
\text { Diabetes } \\
\text { Ulcer } \\
\text { Kidney disease } \\
\text { Liver disease } \\
\text { Anemia } \\
\text { Depression } \\
\text { Osteoarthritis } \\
\text { Back pain } \\
\text { Riieumatoid arthritis }\end{array}$ & $\begin{array}{c}4.3(7) \\
35.4(58) \\
1.8(3) \\
5.5(9) \\
2.4(4) \\
0.6(1) \\
1.2(2) \\
4.9(8) \\
22.0(36) \\
20.1(33) \\
24.4(40) \\
2.4(4)\end{array}$ & $\begin{array}{c}3.2(3) \\
22.6(21) \\
2.2(2) \\
6.5(6) \\
5.4(5) 14.0(13) \\
12.9(12) \\
24.7(23) \\
1.1(1) \\
0.0(0) \\
3.2(3) \\
7.5(7)\end{array}$ & $\begin{array}{c}3.6(5) \\
31.4(43) \\
4.4(6) \\
11.7(16) \\
4.4(6) \\
1.5(2) \\
2.9(4) \\
11.7(16) \\
27.0(37) \\
17.5(24) \\
34.3(47) \\
5.8(8)\end{array}$ & $\begin{array}{l}\text { NS } \\
\text { NS } \\
\text { NS } \\
\text { NS } \\
\text { NS } \\
\text { NS } \\
\text { NS } \\
\text { NS } \\
\text { NS } \\
\text { NS } \\
\text { NS } \\
\text { NS }\end{array}$ \\
\hline $\begin{array}{l}\text { Exercise on a regular basis } \\
\text { Yes } \\
\text { No }\end{array}$ & $\begin{array}{l}74.4(122) \\
25.6(42)\end{array}$ & $\begin{array}{l}70.7(65) \\
29.3(27)\end{array}$ & $\begin{array}{l}63.7(86) \\
36.3(49)\end{array}$ & NS \\
\hline Diagnosed with mastitis & $15.4(25)$ & $10.9(10)$ & $8.9(12)$ & NS \\
\hline
\end{tabular}




\begin{tabular}{|c|c|c|c|c|}
\hline \multirow[t]{2}{*}{ Characteristic } & $\begin{array}{l}\text { No Pain (0) } \\
164(41.6 \%)\end{array}$ & $\begin{array}{c}\text { Mild Pain (1) } 93 \\
(23.6 \%)\end{array}$ & $\begin{array}{c}\text { Moderate Pain (2) } \\
137(34.8 \%)\end{array}$ & \multirow[t]{2}{*}{ Statistics } \\
\hline & Mean (SD) & Mean (SD) & Mean (SD) & \\
\hline $\begin{array}{l}\text { Yes } \\
\text { No }\end{array}$ & $84.6(137)$ & $89.1(82)$ & $91.1(123)$ & \\
\hline $\begin{array}{l}\text { Diagnosed with fibrocystic disease } \\
\text { Yes } \\
\text { No }\end{array}$ & $\begin{array}{c}17.2(27) \\
82.8(130)\end{array}$ & $\begin{array}{l}22.8(21) \\
77.2(71)\end{array}$ & $\begin{array}{c}18.3(24) \\
81.7(107)\end{array}$ & NS \\
\hline $\begin{array}{l}\text { Ever breast fed } \\
\text { Yes } \\
\text { No }\end{array}$ & $\begin{array}{l}54.0(88) \\
46.0(75)\end{array}$ & $\begin{array}{l}43.0(40) \\
57.0(53)\end{array}$ & $\begin{array}{l}41.6(57) \\
58.4(80)\end{array}$ & NS \\
\hline $\begin{array}{l}\text { Surgery to affected breast unrelated to cancer } \\
\text { Yes } \\
\text { No }\end{array}$ & $\begin{array}{c}11.0(18) \\
89.0(146)\end{array}$ & $\begin{array}{l}10.8(10) \\
89.2(83)\end{array}$ & $\begin{array}{c}9.5(13) \\
90.5(124)\end{array}$ & NS \\
\hline $\begin{array}{l}\text { Surgery on affected arm not related to cancer } \\
\text { Yes } \\
\text { No }\end{array}$ & $\begin{array}{c}4.3(7) \\
95.7(157)\end{array}$ & $\begin{array}{c}1.1(1) \\
98.9(92)\end{array}$ & $\begin{array}{c}4.4(6) \\
95.6(131)\end{array}$ & NS \\
\hline $\begin{array}{l}\text { Surgery on affected hand not related to cancer } \\
\text { Yes } \\
\text { No }\end{array}$ & $\begin{array}{c}6.1(10) \\
93.9(154)\end{array}$ & $\begin{array}{c}4.3(4) \\
95.7(89)\end{array}$ & $\begin{array}{c}5.1(7) \\
94.9(130)\end{array}$ & NS \\
\hline $\begin{array}{l}\text { Injury to affected arm } \\
\text { Yes } \\
\text { No }\end{array}$ & $\begin{array}{c}15.2(25) \\
84.8(139)\end{array}$ & $\begin{array}{l}15.1(14) \\
84.9(79)\end{array}$ & $\begin{array}{c}13.1(18) \\
86.9(119)\end{array}$ & NS \\
\hline $\begin{array}{l}\text { Injury to affected hand } \\
\text { Yes } \\
\text { No }\end{array}$ & $\begin{array}{c}7.3(12) \\
92.7(152)\end{array}$ & $\begin{array}{c}9.7(9) \\
90.3(84)\end{array}$ & $\begin{array}{c}12.4(17) \\
87.6(120)\end{array}$ & NS \\
\hline $\begin{array}{l}\text { Prior hysterectomy } \\
\text { Yes } \\
\text { No }\end{array}$ & $\begin{array}{c}15.2(25) \\
84.8(139)\end{array}$ & $\begin{array}{c}7.5(7) \\
92.5(86)\end{array}$ & $\begin{array}{c}15.3(21) \\
84.7(116)\end{array}$ & NS \\
\hline $\begin{array}{l}\text { Prior oophorectomy } \\
\text { Yes } \\
\text { No }\end{array}$ & $\begin{array}{c}12.9(21) \\
87.1(142)\end{array}$ & $\begin{array}{c}7.5(7) \\
92.5(86)\end{array}$ & $\begin{array}{c}10.2(14) \\
89.8(123)\end{array}$ & NS \\
\hline $\begin{array}{l}\text { Gone through menopause } \\
\text { Yes } \\
\text { No }\end{array}$ & $\begin{array}{l}69.6(112) \\
30.4(49)\end{array}$ & $\begin{array}{l}56.7(51) \\
43.3(39)\end{array}$ & $\begin{array}{l}62.9(83) \\
37.1(49)\end{array}$ & NS \\
\hline $\begin{array}{l}\text { Received neoadjuvant chemotherapy } \\
\text { Yes } \\
\text { No }\end{array}$ & $\begin{array}{c}8.0(13) \\
92.0(150)\end{array}$ & $\begin{array}{l}23.7(22) \\
76.3(71)\end{array}$ & $\begin{array}{l}31.4(43) \\
68.6(94)\end{array}$ & $\begin{array}{c}\mathrm{X}^{2}=26.76, \mathrm{p}<.0001 \\
0<1 \text { and } 2\end{array}$ \\
\hline $\begin{array}{l}\text { On hormonal replacement therapy prior to surgery } \\
\text { Yes } \\
\text { No }\end{array}$ & $\begin{array}{c}21.1(36) \\
77.9(127)\end{array}$ & $\begin{array}{l}12.9(12) \\
87.1(81)\end{array}$ & $\begin{array}{c}14.0(19) \\
86.0(117)\end{array}$ & NS \\
\hline $\begin{array}{l}\text { stage of disease } \\
\text { Stage } 0 \\
\text { Stage } 1 \\
\text { Stage IIA and IIB } \\
\text { Stage IIIA, IIIB, IIIMC, and IV }\end{array}$ & $\begin{array}{c}24.4(40) \\
45.1(74) \\
28.7(47) \\
1.8(3)\end{array}$ & $\begin{array}{c}18.3(17) \\
34.4(32) \\
38.7(36) \\
8.6(8)\end{array}$ & $\begin{array}{c}11.7(16) \\
32.1(44) \\
40.9(56) \\
15.3(21)\end{array}$ & $\begin{array}{c}\mathrm{KW}, \mathrm{p}<.0001 \\
0<1 \text { and } 2\end{array}$ \\
\hline $\begin{array}{l}\text { Estrogen receptor status } \\
\text { Positive } \\
\text { Negative }\end{array}$ & $\begin{array}{c}82.2(134) \\
17.8(29)\end{array}$ & $\begin{array}{l}73.1(68) \\
26.9(25)\end{array}$ & $\begin{array}{l}74.5(102) \\
25.5(35)\end{array}$ & NS \\
\hline $\begin{array}{l}\text { Progesterone receptor status } \\
\text { Positive } \\
\text { Negative }\end{array}$ & $\begin{array}{l}73.0(119) \\
27.0(44)\end{array}$ & $\begin{array}{l}64.5(60) \\
35.5(33)\end{array}$ & $\begin{array}{l}71.5(98) \\
28.5(39)\end{array}$ & NS \\
\hline $\begin{array}{l}\text { HER2/neu receptor positive } \\
\text { Yes } \\
\text { No }\end{array}$ & $\begin{array}{c}12.8(18) \\
87.2(123)\end{array}$ & $\begin{array}{l}17.6(15) \\
82.4(70)\end{array}$ & $\begin{array}{c}19.4(25) \\
80.6(104)\end{array}$ & NS \\
\hline $\begin{array}{l}\text { BRCA1 and BRCA2 genetic testing } \\
\text { Positive } \\
\text { Negative } \\
\text { Not done }\end{array}$ & $\begin{array}{c}3.1(5) \\
8.0(13) \\
88.9(144)\end{array}$ & $\begin{array}{c}1.1(1) \\
17.2(16) \\
81.7(76)\end{array}$ & $\begin{array}{c}1.5(2) \\
9.6(13) \\
88.9(120)\end{array}$ & NS \\
\hline
\end{tabular}




\begin{tabular}{|c|c|c|c|c|}
\hline \multirow[t]{2}{*}{ Characteristic } & $\begin{array}{l}\text { No Pain (0) } \\
164(41.6 \%)\end{array}$ & $\begin{array}{l}\text { Mild Pain (1) } 93 \\
\quad(23.6 \%)\end{array}$ & $\begin{array}{c}\text { Moderate Pain (2) } \\
\quad 137(34.8 \%)\end{array}$ & \multirow[t]{2}{*}{ Statistics } \\
\hline & Mean (SD) & Mean (SD) & Mean (SD) & \\
\hline $\begin{array}{l}\text { Used NSAID preoperatively } \\
\text { Yes } \\
\text { No }\end{array}$ & $\begin{array}{c}3.7(6) \\
96.3(157)\end{array}$ & $\begin{array}{c}0.0(0) \\
100.0(93)\end{array}$ & $\begin{array}{c}3.7(5) \\
96.3(131)\end{array}$ & NS \\
\hline $\begin{array}{l}\text { Pain in breast prior to surgery } \\
\text { Yes } \\
\text { No }\end{array}$ & $\begin{array}{c}15.0(24) \\
85.0(136)\end{array}$ & $\begin{array}{l}35.2(32) \\
64.8(59)\end{array}$ & $\begin{array}{l}38.5(52) \\
61.5(83)\end{array}$ & $\begin{array}{c}\mathrm{X}^{2}=23.15, \mathrm{p}<.0001 \\
0<1 \text { and } 2\end{array}$ \\
\hline $\begin{array}{l}\text { Swelling in affected breast } \\
\text { Yes } \\
\text { No }\end{array}$ & $\begin{array}{c}4.3(7) \\
95.7(157)\end{array}$ & $\begin{array}{c}5.4(5) \\
94.6(88)\end{array}$ & $\begin{array}{c}13.9(19) \\
86.1(118)\end{array}$ & $\begin{array}{c}\mathrm{X}^{2}=10.53, \mathrm{p}=.005 \\
0<2\end{array}$ \\
\hline $\begin{array}{l}\text { Numbness in affected breast } \\
\text { Yes } \\
\text { No }\end{array}$ & $\begin{array}{c}1.8(3) \\
98.2(161)\end{array}$ & $\begin{array}{c}4.3(4) \\
95.7(89)\end{array}$ & $\begin{array}{c}6.6(9) \\
93.4(128)\end{array}$ & NS \\
\hline $\begin{array}{l}\text { Strange sensations in affected breast } \\
\text { Yes } \\
\text { No }\end{array}$ & $\begin{array}{c}20.1(33) \\
79.9(131)\end{array}$ & $\begin{array}{l}34.4(32) \\
65.6(61)\end{array}$ & $\begin{array}{c}26.3(36) \\
73.7(101)\end{array}$ & $\begin{array}{c}\mathrm{X}^{2}=6.40, \mathrm{p}=.041 \\
0<1\end{array}$ \\
\hline $\begin{array}{l}\text { Hardness in affected breast } \\
\text { Yes } \\
\text { No }\end{array}$ & $\begin{array}{c}14.0(23) \\
86.0(141)\end{array}$ & $\begin{array}{l}16.1(15) \\
83.9(78)\end{array}$ & $\begin{array}{c}24.1(33) \\
75.9(104)\end{array}$ & NS \\
\hline
\end{tabular}

Abbreviations: $\mathrm{KW}=$ Kruskal Wallis; $\mathrm{NS}=$ Not significant, $\mathrm{SD}=$ standard deviation 
Table 5

Differences in Preoperative Symptom and Quality of Life Scores Among the Breast Pain Classes

\begin{tabular}{|c|c|c|c|c|}
\hline \multirow[t]{2}{*}{ Symptom and Quality of Life Scores } & $\begin{array}{l}\text { No Pain (0) } \\
164(41.6 \%)\end{array}$ & $\begin{array}{l}\text { Mild Pain (1) } \\
93(23.6 \%)\end{array}$ & $\begin{array}{c}\text { Moderate Pain (2) } \\
137(34.8 \%)\end{array}$ & \multirow[t]{2}{*}{ Statistics } \\
\hline & Mean (SD) & Mean (SD) & Mean (SD) & \\
\hline \multicolumn{5}{|l|}{ SYMPTOM SCORES PRIOR TO SURGERY } \\
\hline Center for Epidemiological Studies- Depression score & $12.6(9.6)$ & $13.0(9.8)$ & $15.4(9.6)$ & $\begin{array}{c}\mathrm{F}=3.19, \mathrm{p}=.0420 \\
<2\end{array}$ \\
\hline Trait anxiety & $34.3(8.8)$ & $34.3(8.7)$ & $37.3(9.3)$ & $\begin{array}{c}\mathrm{F}=4.83, \mathrm{p}=.009 \\
0 \text { and } 1<2\end{array}$ \\
\hline State anxiety & $40.6(14.2)$ & $41.7(12.6)$ & $43.0(13.0)$ & NS \\
\hline General Sleep Disturbance Scale score & $44.1(20.9)$ & $47.4(22.2)$ & $54.4(20.9)$ & $\begin{array}{c}\mathrm{F}=8.67, \mathrm{p}<.0001 \\
0<2\end{array}$ \\
\hline Lee Fatigue Subscale score & $2.6(2.3)$ & $3.2(2.2)$ & $3.7(2.4)$ & $\begin{array}{c}\mathrm{F}=8.26, \mathrm{p}<.0001 \\
0<2\end{array}$ \\
\hline Lee Energy Subscale score & $5.3(2.7)$ & $4.6(2.2)$ & $4.7(2.4)$ & $\begin{array}{c}\mathrm{F}=3.56, \mathrm{p}=.029 \\
\text { No significant pairwise } \\
\text { post hocs }\end{array}$ \\
\hline Attentional Function Index score & $7.0(2.0)$ & $6.5(1.9)$ & $6.2(1.9)$ & $\begin{array}{c}\mathrm{F}=6.78, \mathrm{p}=.001 \\
0>2\end{array}$ \\
\hline \multicolumn{5}{|c|}{ QUALITY OF LIFE SUBSCALE AND TOTAL SCORES PRIOR TO SURGERY } \\
\hline Physical well-being score & $8.6(1.2)$ & $8.0(1.5)$ & $7.2(1.8)$ & $\begin{array}{c}\mathrm{F}=31.13, \mathrm{p}<.0001 \\
0>1>2\end{array}$ \\
\hline Psychological well-being score & $6.3(1.7)$ & $5.8(1.7)$ & $5.2(1.8)$ & $\begin{array}{c}\mathrm{F}=14.32, \mathrm{p}<.0001 \\
0 \text { and } 1>2\end{array}$ \\
\hline Social well-being score & $7.7(1.6)$ & $6.8(1.9)$ & $6.1(2.1)$ & $\begin{array}{c}\mathrm{F}=28.98, \mathrm{p}<.0001 \\
0>1>2\end{array}$ \\
\hline Spiritual well-being score & $5.7(1.8)$ & $5.6(1.6)$ & $5.9(1.9)$ & NS \\
\hline Total quality of life score & $6.9(1.2)$ & $6.4(1.2)$ & $5.9(1.4)$ & $\begin{array}{c}\mathrm{F}=23.46, \mathrm{p}<.0001 \\
0>1>2\end{array}$ \\
\hline
\end{tabular}

Abbreviations: NS = Not significant, $\mathrm{SD}=$ standard deviation 
Table 6

Differences in Intraoperative Characteristics Among the Arm/Shoulder Pain Classes

\begin{tabular}{|c|c|c|c|c|}
\hline \multirow[t]{2}{*}{ Characteristic } & $\begin{array}{l}\text { No Pain }(0) \\
164(41.6 \%)\end{array}$ & $\begin{array}{l}\text { Mild Pain (1) } \\
93(23.6 \%)\end{array}$ & $\begin{array}{c}\text { Moderate Pain (2) } \\
137(34.8 \%)\end{array}$ & \multirow[t]{2}{*}{ Statistics } \\
\hline & Mean (SD) & Mean (SD) & Mean (SD) & \\
\hline Number of lymph nodes removed & $3.3(4.6)$ & $6.6(5.9)$ & $8.0(8.2)$ & $\begin{array}{c}\mathrm{F}=20.91, \mathrm{p}<.0001 \\
0<1 \text { and } 2\end{array}$ \\
\hline Number of positive lymph nodes & $0.3(1.1)$ & $1.0(1.9)$ & $1.5(3.1)$ & $\begin{array}{c}\mathrm{F}=9.55, \mathrm{p}<.0001 \\
0<2\end{array}$ \\
\hline \multirow[t]{2}{*}{ Number of drains placed during surgery } & $0.3(0.6)$ & $0.5(0.7)$ & $0.7(0.8)$ & $\begin{array}{c}\mathrm{F}=13.18, \mathrm{p}<.0001 \\
0<2\end{array}$ \\
\hline & $\%(\mathrm{~N})$ & $\%(\mathrm{~N})$ & $\%(\mathrm{~N})$ & \\
\hline $\begin{array}{l}\text { Type of surgery } \\
\text { Breast conserving } \\
\text { Mastectomy }\end{array}$ & $\begin{array}{l}86.0(141) \\
14.0(23)\end{array}$ & $\begin{array}{l}79.6(74) \\
20.4(19)\end{array}$ & $\begin{array}{l}74.5(102) \\
25.5(35)\end{array}$ & $\begin{array}{c}\mathrm{X}^{2}=6.36, \mathrm{p}<.04 \\
0<2\end{array}$ \\
\hline $\begin{array}{l}\text { Location of cancer } \\
\text { Right breast } \\
\text { Left breast }\end{array}$ & $\begin{array}{l}43.3(71) \\
56.7(93)\end{array}$ & $\begin{array}{l}46.2(43) \\
53.8(50)\end{array}$ & $\begin{array}{l}51.8(71) \\
48.2(66)\end{array}$ & NS \\
\hline $\begin{array}{l}\text { Surgery done on } \\
\text { Dominant side } \\
\text { Nondominant side }\end{array}$ & $\begin{array}{l}45.1(74) \\
54.9(90)\end{array}$ & $\begin{array}{l}48.4(45) \\
51.6(48)\end{array}$ & $\begin{array}{l}47.4(65) \\
52.6(72)\end{array}$ & NS \\
\hline $\begin{array}{l}\text { Sentinel lymph node biopsy } \\
\text { Yes } \\
\text { No }\end{array}$ & $\begin{array}{l}79.9(131) \\
20.1(33)\end{array}$ & $\begin{array}{l}86.0(80) \\
14.0(13)\end{array}$ & $\begin{array}{l}83.9(115) \\
16.1(22)\end{array}$ & NS \\
\hline $\begin{array}{l}\text { Axillary lymph node dissection } \\
\text { Yes } \\
\text { No }\end{array}$ & $\begin{array}{c}19.6(32) \\
80.4(131)\end{array}$ & $\begin{array}{l}47.3(44) \\
52.7(49)\end{array}$ & $\begin{array}{l}51.1(70) \\
48.9(67)\end{array}$ & $\begin{array}{c}\mathrm{X}^{2}=36.95, \mathrm{p}<.0001 \\
0<1 \text { and } 2\end{array}$ \\
\hline Intercostobrachial nerve sacrificed Yes No Unable to determine & $\begin{array}{c}0.6(1) \\
10.4(17) \\
89.0(145)\end{array}$ & $\begin{array}{c}3.2(3) \\
11.8(11) \\
84.9(79)\end{array}$ & $\begin{array}{c}6.6(9) \\
8.0(11) \\
85.4(117)\end{array}$ & NS \\
\hline $\begin{array}{l}\text { Intraoperative wound infiltration with local anesthetic } \\
\text { Yes } \\
\text { No } \\
\text { Unable to determine }\end{array}$ & $\begin{array}{l}72.6(119) \\
7.9(13) \\
19.5(32)\end{array}$ & $\begin{array}{l}54.8(51) \\
14.0(13) \\
31.2(29)\end{array}$ & $\begin{array}{l}56.2(77) \\
10.9(15) \\
32.8(45)\end{array}$ & $\begin{array}{c}\mathrm{X}^{2}=12.29, \mathrm{p}=.015 \\
0>1 \text { and } 2\end{array}$ \\
\hline $\begin{array}{l}\text { Intraoperative radiation therapy } \\
\text { Yes } \\
\text { No }\end{array}$ & $\begin{array}{c}3.7(6) \\
96.3(158)\end{array}$ & $\begin{array}{c}4.3(4) \\
95.7(89)\end{array}$ & $\begin{array}{c}3.7(5) \\
96.3(131)\end{array}$ & NS \\
\hline $\begin{array}{l}\text { Reconstruction at the time of surgery } \\
\text { Yes } \\
\text { No }\end{array}$ & $\begin{array}{l}20.7(34) \\
79.3(130)\end{array}$ & $\begin{array}{l}20.7(19) \\
79.3(73)\end{array}$ & $\begin{array}{c}24.1(33) \\
75.9(104)\end{array}$ & NS \\
\hline
\end{tabular}

Abbreviations: NS = Not significant, $\mathrm{SD}=$ standard deviation 
Table 7

Differences in Postoperative Clinical Characteristics Among the Arm/Shoulder Pain Classes

\begin{tabular}{|c|c|c|c|c|}
\hline \multirow[t]{2}{*}{ Characteristic } & $\begin{array}{l}\text { No Pain (0) } \\
164(41.6 \%)\end{array}$ & $\begin{array}{c}\text { Mild Pain (1) } \\
93(23.6 \%)\end{array}$ & $\begin{array}{c}\text { Moderate Pain (2) } \\
137(34.8 \%)\end{array}$ & \multirow[t]{2}{*}{ Statistics } \\
\hline & Mean (SD) & Mean (SD) & Mean (SD) & \\
\hline Number of postoperative complications & $0.2(0.5)$ & $0.2(0.4)$ & $0.3(0.6)$ & $\begin{array}{c}\mathrm{F}=3.67, \mathrm{p}=.026 \\
0<2\end{array}$ \\
\hline Severity of average postoperative pain & $3.0(2.3)$ & $3.7(2.3)$ & $5.0(2.2)$ & $\begin{array}{c}\mathrm{F}=28.21, \mathrm{p}<.0001 \\
0 \text { and } 1<2\end{array}$ \\
\hline Severity of worst postoperative pain & $4.2(2.7)$ & $5.0(2.6)$ & $6.6(2.4)$ & $\begin{array}{c}\mathrm{F}=31.16, \mathrm{p}<.0001 \\
0<1<2\end{array}$ \\
\hline Amount of relief from analgesics (\%) & $81.1(25.5)$ & $81.3(20.2)$ & $74.8(21.5)$ & $\begin{array}{c}\mathrm{F}=3.16, \mathrm{p}=.043 \\
\text { No significant pairwise post } \\
\text { hocs }\end{array}$ \\
\hline \multirow[t]{2}{*}{ Satisfaction with postoperative pain treatment } & $9.0(1.9)$ & $8.6(2.1)$ & $8.1(2.3)$ & $\begin{array}{c}\mathrm{F}=6.39, \mathrm{p}=.002 \\
0>2\end{array}$ \\
\hline & $\%(\mathrm{~N})$ & $\%(\mathrm{~N})$ & $\%(\mathrm{~N})$ & \\
\hline $\begin{array}{l}\text { Placement of surgical drain } \\
\text { None } \\
\text { Only in breast } \\
\text { Only in axilla } \\
\text { In both breast and axilla }\end{array}$ & $\begin{array}{c}75.0(123) \\
17.7(29) \\
6.7(11) \\
0.6(1)\end{array}$ & $\begin{array}{l}57.0(53) \\
16.1(15) \\
20.4(19) \\
6.5(6)\end{array}$ & $\begin{array}{l}48.9(67) \\
13.1(18) \\
27.7(38) \\
10.2(14)\end{array}$ & $\begin{array}{c}\mathrm{X}^{2}=42.72, \mathrm{p}<.0001 \\
\text { None- } 0>1 \text { and } 2 \\
\text { Only in breast }-\mathrm{NS} \\
\text { Only in axilla }-0<1 \text { and } 2 \\
\text { In both }-0<2\end{array}$ \\
\hline $\begin{array}{l}\text { Had one to four postoperative complications } \\
\text { Yes } \\
\text { No }\end{array}$ & $\begin{array}{c}12.2(20) \\
87.8(144)\end{array}$ & $\begin{array}{l}14.0(13) \\
86.0(80)\end{array}$ & $\begin{array}{c}24.1(33) \\
75.9(104)\end{array}$ & $\begin{array}{c}\mathrm{X}^{2}=8.24, \mathrm{p}=.016 \\
0<2\end{array}$ \\
\hline $\begin{array}{l}\text { Had a seroma } \\
\text { Yes } \\
\text { No }\end{array}$ & $\begin{array}{c}7.3(12) \\
92.7(152)\end{array}$ & $\begin{array}{c}7.5(7) \\
92.5(86)\end{array}$ & $\begin{array}{l}14.6(20) \\
85.4(117)\end{array}$ & NS \\
\hline $\begin{array}{l}\text { Had a hematoma } \\
\text { Yes } \\
\text { No }\end{array}$ & $\begin{array}{c}3.7(6) \\
96.3(158)\end{array}$ & $\begin{array}{c}4.3(4) \\
95.7(89)\end{array}$ & $\begin{array}{c}8.0(11) \\
92.0(126)\end{array}$ & NS \\
\hline $\begin{array}{l}\text { Had bleeding } \\
\text { Yes } \\
\text { No }\end{array}$ & $\begin{array}{c}1.2(2) \\
98.8(162)\end{array}$ & $\begin{array}{c}0.0(0) \\
100.0(93)\end{array}$ & $\begin{array}{c}2.2(3) \\
97.8(134)\end{array}$ & NS \\
\hline $\begin{array}{l}\text { Had a wound infection } \\
\text { Yes } \\
\text { No }\end{array}$ & $\begin{array}{c}3.0(5) \\
97.0(159)\end{array}$ & $\begin{array}{c}4.3(4) \\
95.7(89)\end{array}$ & $\begin{array}{c}5.1(7) \\
94.9(130)\end{array}$ & NS \\
\hline $\begin{array}{l}\text { Received radiation therapy during the } 6 \text { months } \\
\text { Yes } \\
\text { No }\end{array}$ & $\begin{array}{l}59.1(97) \\
40.9(67)\end{array}$ & $\begin{array}{l}54.8(51) \\
45.2(42)\end{array}$ & $\begin{array}{l}54.7(75) \\
45.3(62)\end{array}$ & NS \\
\hline $\begin{array}{l}\text { Received adjuvant chemotherapy during the } 6 \text { months } \\
\text { Yes } \\
\text { No }\end{array}$ & $\begin{array}{c}27.4(45) \\
72.6(119)\end{array}$ & $\begin{array}{l}38.7(36) \\
61.3(57)\end{array}$ & $\begin{array}{l}38.0(52) \\
62.0(85)\end{array}$ & NS \\
\hline $\begin{array}{l}\text { Received hormonal therapy during the } 6 \text { months } \\
\text { Yes } \\
\text { No }\end{array}$ & $\begin{array}{l}45.1(74) \\
54.9(90)\end{array}$ & $\begin{array}{l}45.2(42) \\
54.8(51)\end{array}$ & $\begin{array}{l}38.0(52) \\
62.0(85)\end{array}$ & NS \\
\hline $\begin{array}{l}\text { Received biological therapy during the } 6 \text { months } \\
\text { Yes } \\
\text { No }\end{array}$ & $\begin{array}{c}5.5(9) \\
94.5(155)\end{array}$ & $\begin{array}{l}17.2(16) \\
82.8(77)\end{array}$ & $\begin{array}{c}12.4(17) \\
87.6(120)\end{array}$ & $\begin{array}{c}\mathrm{X}^{2}=9.23, \mathrm{p}=.010 \\
0<1\end{array}$ \\
\hline $\begin{array}{l}\text { Received complementary therapy during the } 6 \text { months } \\
\text { Yes } \\
\text { No }\end{array}$ & $\begin{array}{l}25.6(42) \\
74.4(122)\end{array}$ & $\begin{array}{l}29.0(27) \\
71.0(66)\end{array}$ & $\begin{array}{l}28.5(39) \\
71.5(98)\end{array}$ & NS \\
\hline $\begin{array}{l}\text { Received physical therapy during the } 6 \text { months } \\
\text { Yes } \\
\text { No }\end{array}$ & $\begin{array}{c}10.4(17) \\
89.6(147)\end{array}$ & $\begin{array}{l}12.9(12) \\
87.1(81)\end{array}$ & $\begin{array}{l}24.8(34) \\
75.2(103)\end{array}$ & $\begin{array}{c}\mathrm{X}^{2}=12.47, \mathrm{p}=.002 \\
0<2\end{array}$ \\
\hline
\end{tabular}




\begin{tabular}{|c|c|c|c|c|}
\hline \multirow[t]{2}{*}{ Characteristic } & $\begin{array}{l}\text { No Pain (0) } \\
164(41.6 \%)\end{array}$ & $\begin{array}{c}\text { Mild Pain (1) } \\
93(23.6 \%)\end{array}$ & $\begin{array}{c}\text { Moderate Pain (2) } \\
137(34.8 \%)\end{array}$ & \multirow[t]{2}{*}{ Statistics } \\
\hline & Mean (SD) & Mean (SD) & Mean (SD) & \\
\hline $\begin{array}{l}\text { Had breast reconstruction during the } 6 \text { months } \\
\text { Yes } \\
\text { No }\end{array}$ & $\begin{array}{c}6.1(10) \\
93.9(154)\end{array}$ & $\begin{array}{c}7.5(7) \\
92.5(86)\end{array}$ & $\begin{array}{c}8.0(11) \\
92.0(126)\end{array}$ & NS \\
\hline $\begin{array}{l}\text { Breast cancer recurred during the } 6 \text { months } \\
\text { Yes } \\
\text { No }\end{array}$ & $\begin{array}{c}0.0(0) \\
100.0(164)\end{array}$ & $\begin{array}{c}0.0(0) \\
100.0(93)\end{array}$ & $\begin{array}{c}0.0(0) \\
100.0(137)\end{array}$ & NS \\
\hline $\begin{array}{l}\text { Had re-excision or mastectomy during the } 6 \text { months } \\
\text { Yes } \\
\text { No }\end{array}$ & $\begin{array}{c}24.4(40) \\
75.6(124)\end{array}$ & $\begin{array}{l}24.7(23) \\
75.3(70)\end{array}$ & $\begin{array}{l}33.6(46) \\
66.4(91)\end{array}$ & NS \\
\hline $\begin{array}{l}\text { Any other surgery during the } 6 \text { months } \\
\text { Yes } \\
\text { No }\end{array}$ & $\begin{array}{c}8.5(14) \\
91.5(150)\end{array}$ & $\begin{array}{l}12.9(12) \\
87.1(81)\end{array}$ & $\begin{array}{c}10.2(14) \\
89.8(123)\end{array}$ & NS \\
\hline $\begin{array}{l}\text { Evidence of metastatic disease during the } 6 \text { months } \\
\text { Yes } \\
\text { No }\end{array}$ & $\begin{array}{c}0.0(0) \\
100.0(164)\end{array}$ & $\begin{array}{c}1.1(1) \\
98.9(92)\end{array}$ & $\begin{array}{c}0.0(0) \\
100.0(137)\end{array}$ & NS \\
\hline
\end{tabular}

Abbreviations: NS = Not significant, $\mathrm{SD}=$ standard deviation 